\title{
Elective transfer from cardiopulmonary bypass to centrifugal blood pump support in very high-risk cardiac surgery
}

Stephen Westaby, BSc, FRCS, MS, PhD, FETCS, FESC, FACC, FICA, Lognathen Balacumaraswami, MBBS, FRCS, FRCS (CTh), Betsy J. Evans, MRCS, Gabriele B. Bertoni, MD, Xu Y. Jin, MD, PhD, Desiree Robson, RN,

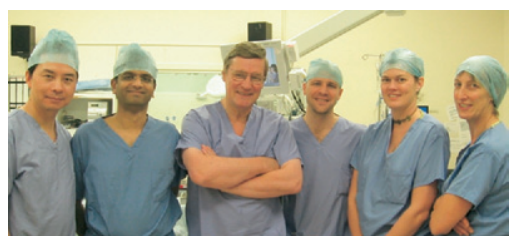

Drs Jin, Balacumaraswami, Westaby, Bertoni, Evans, and Grebenik (left to right) and Catherine R. Grebenik, MD, Oxford, UK

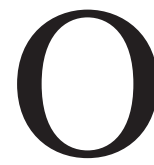

perations on patients with advanced heart failure carry substantial mortality, but this group has much to gain if they survive. Conventionally, the intra-aortic balloon pump (IABP) is used to assist weaning from cardiopulmonary bypass (CPB), but postischemic stunning may further impair myocardial function. This results in renal shutdown and deranged metabolic status. In established cardiogenic shock, attempted salvage with a left ventricular assist device (LVAD) carries a $50 \%$ to $75 \%$ mortality. ${ }^{1,2}$ To improve outcome in borderline survival situations, we decided to wean directly from $\mathrm{CPB}$ to a short-term centrifugal blood pump.

\section{Methods}

The patients at highest risk are selected before surgery. Candidates may have left ventricular ejection fraction less than $20 \%$, impaired renal function, or aortoiliac disease precluding IABP use. LVAD implantation is undertaken during 30 minutes of reperfusion, before discontinuation of $\mathrm{CPB}$. Conduits for the inflow and outflow cannulas are used to improve the safety of decannulation (Figure 1).

The Levitronix CentriMag pump (Levitronix LLC, Waltham, Mass) has been described previously. ${ }^{1}$ The pump head priming volume is $31 \mathrm{~mL}$. The system is filled during reperfusion and deairing of the native heart. When the patient is weaned from $\mathrm{CPB}$, the LVAD provides 3 to $4 \mathrm{~L} / \mathrm{min}$ flow. Antegrade cardiac ejection provides systemic pulsatility. Combined output from the device and the left ventricle is around $3.0 \mathrm{~L} / \mathrm{m}^{2} \cdot \min$. Transesophageal echocardiography confirms the position of the inflow cannula and the efficacy of deairing.

After protamine, the sternotomy is closed to allow extubation during support. To minimize bleeding, no anticoagulation is given for 12 hours. Once the chest tube drainage is less than $50 \mathrm{~mL} / \mathrm{h}$, heparin infusion provides an activated partial thromboplastin time ratio of 1.5 to 2.5 . Myocardial function is as-

From John Radcliffe Hospital, Oxford, UK.

Received for publication Sept 8, 2006; accepted for publication Sept 28, 2006.

Address for reprints: Stephen Westaby, FRCS, MS, PhD, FETCS, FESC, FACC, FICA, John Radcliffe Hospital, Headley Way, Headington, OX3 9DU, Oxford, UK (E-mail: swestaby@ ahf.org.uk).

J Thorac Cardiovasc Surg 2007;133:577-8

$0022-5223 / \$ 32.00$

Copyright $\odot 2007$ by The American Association for Thoracic Surgery doi:10.1016/j.jtcvs.2006.09.035 sessed daily with pump flow turned down to $2.0 \mathrm{~L} /\left(\mathrm{m}^{2} \cdot \mathrm{min}\right)$. Postischemic dysfunction normally resolves during 3 to 7 days. After sustainable improvement has been achieved, the pump is switched off, the cannulas are withdrawn, and the grafts are ligated close to their insertion.

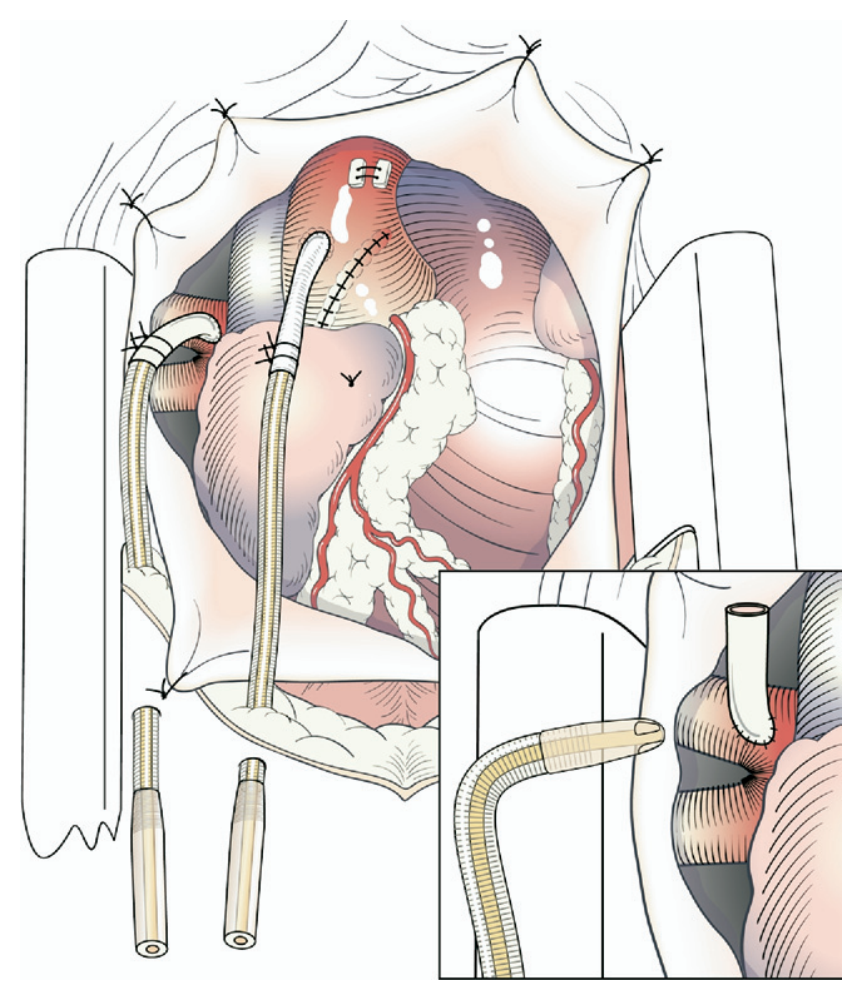

Figure 1. Tube of descending aortic homograft $(8 \mathrm{~cm}$ length $\times 10$ $\mathrm{mm}$ diameter) is sewn to incision at junction of superior pulmonary vein with left atrium. Through this conduit is introduced $32 \mathrm{~F}$ right-angled, wire-reinforced venous cannula into center of left atrium. Ligatures are placed around homograft to retain inflow cannula in position. Distal end of venous cannula is brought through skin below sternotomy wound and then filled by raising left atrial pressure. Dacron polyester fabric graft $(8 \mathrm{~mm})$ is then sewn to ascending aorta with side clamp. Straight arterial inflow cannula (22F) is inserted through this graft, secured in place by ligatures, and brought out through skin adjacent to venous cannula. 
TABLE 1. Patient details: Demographic characteristics, risk stratification, and clinical outcome

\begin{tabular}{|c|c|c|c|c|c|c|c|c|c|c|}
\hline \multirow[b]{2}{*}{ Case } & \multirow{2}{*}{\multicolumn{2}{|c|}{ Age }} & \multirow[b]{2}{*}{$\begin{array}{l}\text { Logistic } \\
\text { EuroSCORE }\end{array}$} & \multirow[b]{2}{*}{ Problem } & \multicolumn{3}{|c|}{ Preoperative } & \multirow[b]{2}{*}{$\begin{array}{l}\text { Support } \\
\text { duration } \\
\text { (d) }\end{array}$} & \multirow[b]{2}{*}{ IABP } & \multirow[b]{2}{*}{$\begin{array}{l}\text { Postoperative } \\
\text { stay (d) }\end{array}$} \\
\hline & & & & & $\begin{array}{l}\text { Left ventricular } \\
\text { ejection } \\
\text { fraction }(\%)\end{array}$ & $\begin{array}{c}\text { serum } \\
\text { creatinine } \\
(\mu \mathrm{mol} / \mathrm{L})\end{array}$ & Operation & & & \\
\hline 1 & 58 & $\mathrm{~F}$ & 4 & $\begin{array}{l}\text { Diabetes, ischemic heart } \\
\text { disease; large anterolateral } \\
\text { scar; nongraftable } \\
\text { coronaries }\end{array}$ & 15 & 83 & $\begin{array}{l}\text { Left ventricular } \\
\text { remodeling }\end{array}$ & 4 & Yes & 10 \\
\hline 3 & 68 & $\mathrm{M}$ & 8 & $\begin{array}{l}\text { Aortic stenosis; idiopathic } \\
\text { dilated cardiomyopathy }\end{array}$ & 10 & 105 & $\begin{array}{l}\text { Aortic valve } \\
\text { replacement }\end{array}$ & 4 & Yes & 14 \\
\hline 4 & 62 & $\mathrm{M}$ & 31 & $\begin{array}{l}\text { Aortic stenosis; chronic renal } \\
\text { failure; aortoiliac occlusion }\end{array}$ & 10 & 341 & $\begin{array}{l}\text { Aortic valve } \\
\text { replacement }\end{array}$ & 5 & No & 23 \\
\hline
\end{tabular}

$I A B P$, Intra-aortic balloon pump; $F$, female; $M$, male; $V S D$, ventricular septal defect.

\section{Clinical Summaries}

Five consecutive case studies are summarized in Table 1. All patients had severe symptoms (New York Heart Association functional class IV) and were considered at high risk for conventional surgery. Patients 1, 2, 3, and 5 had an IABP during anesthetic induction. Patient 4 had aortoiliac occlusion. None required reentry for bleeding. After the operation, the IABP was kept in place for 24 to 36 hours after removal of the LVAD. Patients 2 and 4 required hemofiltration for renal impairment. There were no pumprelated adverse events.

Patient 2 had extensive inferior myocardial infarction with biventricular failure. Forty-eight hours after repair of septal rupture, myocardial function was considered incompatible with recovery, and hepatic failure ensued. Treatment was then withdrawn. Patient 5 returned to the operating room for pump removal on day 3 , but this was deferred for 3 days after observation of the heart.

All 4 patients who walked into the hospital were discharged. Each has shown marked symptomatic relief and improvement in left ventricular function.

\section{Discussion}

Heart failure surgery is an evolving specialty in which risk management plays an important role. As risk profile increases, there is a need for reliable short-term circulatory support to contain mortality. The rationale for elective LVAD deployment is straightforward. The failing heart pumps more than $7000 \mathrm{~L}$ of blood per day against an increased afterload. A dilated heart has greater wall tension and increased myocardial energy demand but suffers reduced subendocardial blood flow. After surgery, ischemiareperfusion injury may trigger the downward spiral into cardiogenic shock and multiorgan failure. Inotropic agents temporarily elevate systemic blood pressure, but they exert deleterious effects by increasing heart rate, afterload, and subendocardial ischemia. ${ }^{3}$ In contrast, the LVAD unloads the ventricle, boosts coronary and systemic blood flows, and promotes myocardial recovery. Some inotropic support may be required to sustain right ventricular contractility.

Conventionally, LVADs are deployed only when death appears certain, but established cardiogenic shock may not be reversible. ${ }^{1,2}$ The willingness to use LVAD technology preemptively to prevent deterioration and promote recovery depends on the safety of the system, the requirement for technical support, and the cost. For recovery after ischemic arrest, the support duration is usually less than 7 days. In this time frame, the Levitronix pump is reliable, safe, and effective. It is readily managed by nursing staff and easily portable. Reoperation for bleeding and decannulation problems are avoided by the use of conduits.

To date this LVAD has been used in more than 300 patients for up to 64 days. The predominant indication $(45 \%)$ has been salvage postcardiotomy support (mean of 9 days), with $53 \%$ survival. We suspect that the $47 \%$ mortality could be reduced by anticipating postoperative deterioration and using the blood pump electively to prevent cardiogenic shock.

\section{References}

1. De Robertis F, Birks EJ, Rogers P, Dreyfus G, Pepper JR, Khaghani A. Clinical performance with the Levitronix Centrimag short-term ventricular assist device. J Heart Lung Transplant. 2006;25:181-6.

2. Goldstein DJ, Oz MC. Mechanical support for post cardiotomy cardiogenic shock. Semin Thorac Cardiovasc Surg. 2000;12:220-8.

3. Katz AM. Influence of altered inotropy and lusiotropy on ventricular pressure-volume loops. J Am Coll Cardiol. 1988;11:438-45. 